\title{
The Balanced Scorecard Design Proposal as an Approach in Performance-Based Budgeting at the Cabinet Secretariat of the Republic of Indonesia
}

\author{
Henni Verawati \\ University of Indonesia, Indonesia
}

\begin{abstract}
The research aims to provide suggestion on strategic maps and balanced scorecards that are appropriate for organization and use the balanced scorecard as an approach in performancebased budgeting. This research uses descriptive analysis method, namely collecting, classifying, and analyzing data which is then systematically described to make conclusions. The results of the study conclude that organizations need to make adjustments to their vision and mission as well as refine their implemented strategies by adding some strategic objectives that have existed before from the balanced scorecard perspective. Furthermore, organizations need to adjust the budgeting system that has been used by using the balanced scorecard approach so that the resulting budgeting can focus on activities that have an influence on achieving predetermined goals and targets which ultimately improve organizational performance.
\end{abstract}

Keywords:Performance-based budgeting; balanced scorecard; strategy map.

\section{Introduction}

Reforms in the public sector budgeting system in Indonesia began to be implemented with the enactment of Law Number 17 of 2003 concerning State Finance, Law Number 1 of 2004 concerning State Treasury and Law Number 15 of 2004 concerning Examination of Management and Responsibility of State Finance. The three laws include changes in the process of drafting and implementing the budget. The most fundamental change is the change from an input / activity budgeting system, into a budgeting system that uses three pillars of the approach, namely unified budgeting, performance based budgeting system and Expenditure Framework Medium Term (multi-term expenditure framework). The three packages of the law are expected to increase professionalism and openness, accountability and transparency in the management of state finances in order to realize good governance in the administration of the state (Cardisiawan, 2008).

However, the implementation of performance-based budgeting has not proceeded properly. There is still a need for a tool that can translate and communicate strategies, performance measurement systems, and strategic management systems that can balance long-term and short-term goals called the Balance Scorecard (Niven, 2003). The Balanced Scorecard is able to translate every vision and strategy into clear targets and measures through four 
perspectives, namely customers, finance, internal business processes, and learning and growth (Kaplan and Norton, 1996).

The evaluation results on the accountability of performance in 2017 by the Ministry of Administrative Reform and Bureaucratic Reform in its letter number B / 646 / M.AA.05 / 2018, dated 26 February 2018, the Cabinet Secretariat scored 70.02 (BB rating). The assessment means that the Cabinet Secretariat has shown that the level of effectiveness and efficiency of budget use is compared with the achievement of its performance, and also the quality of the development of a culture of bureaucratic performance and the implementation of results-oriented governance have shown adequate results, although it still needs improvement.

The following table is a summary of the results of KemanPAN and RB evaluations during $2015-2017$.

Table 1. Evaluation of the Performance Accountability of the Cabinet Secretariat

\begin{tabular}{|l|l|l|l|l|l|l|l|}
\hline \multirow{2}{*}{ No. } & \multirow{2}{*}{ Components assessed } & $\mathbf{2 0 1 5}$ & $\mathbf{2 0 1 6}$ & $\mathbf{2 0 1 7}$ \\
\cline { 3 - 9 } & & Weight & Score & Weight & Score & Weight & Score \\
\hline 1. & Performance Planning & 30 & 21,34 & 30 & 21,60 & 30 & 22,83 \\
\hline 2. & Performance Measurement & 25 & 14,4 & 25 & 15,04 & 25 & 15,39 \\
\hline 3. & Performance Reporting & 15 & 10,50 & 15 & 10,38 & 15 & 10,74 \\
\hline 4. & Internal Evaluation & 10 & 6,11 & 10 & 6,25 & 10 & 6,39 \\
\hline 5. & Performance Achievements & 20 & 13,69 & 20 & 13,75 & 20 & 14,67 \\
\hline & Value of Evaluation Results & 100 & 66,09 & 100 & 67,02 & 100 & 70,02 \\
\hline & $\begin{array}{l}\text { Performance } \\
\text { Accountability }\end{array}$ & & $\mathbf{B}$ & & $\mathbf{B}$ & & $\mathbf{B B}$ \\
\hline
\end{tabular}

Source: Letter of Ministry of Administrative and Bureaucratic Reform Number: B/646/M.AA.05/2018

The table above shows that there is an increase in the achievement of the level of accountability for the use of the Cabinet Secretariat budget. However, the increase that occurred is still not significant, which is only 0.93 points in 2016, while a significant increase in 2017 is equal to 3 points.

Based on the results of an evaluation by the Ministry of Administrative Reform and Bureaucratic Reform which states that the quality of measurements carried out by the Cabinet Secretariat is still not fully on program performance, cascade down, there is no integration between monitoring the progress of performance achievements and action plans. achievement of performance, not optimal utilization of performance reports, and evaluations that have been carried out have not shown the effectiveness of the program.

Based on the background, the research to formulate the issues to be discussed are: a) Has the vision, mission and value of the Cabinet Secretariat been effective and represented the deep beliefs of the organization and reflected in the daily behavior of all employees ?; b) What is the appropriate strategic map for the Cabinet Secretariat that is in line with its strategic plan ?; c) What is the design of the balanced scorecard that is suitable for the Cabinet Secretariat? The purpose of the research is to answer the research problems. 


\section{Theoretical Framework}

Agency theory is an employment contract between a person or more (principal) who appoints another person (agent) to service according to the principal's interests including delegating some authority to the agent (Jensen and Meckling, 1976, in McCue and Prier). Furthermore, Stassart \& de Visscher (2005) in Legrain and Auwers (2006) states that the principal authority who delegates some of its authority to the agent is poured through a contract that regulates the rights and obligations of the parties, including the agent's performance results derived from the resources provided by the principal.

This agency theory can be applied in relations between the people as principals and the Cabinet Secretariat as an agent, where the Cabinet Secretariat must be able to account for the budget used by showing an increase in performance achievements in accordance with previously set targets.

According to Renyowijoyo (2013: 53), the state budget can be interpreted as: a) expenditure / expenditure plan; b) expenditure receipt / financing plan; c) covers a certain period of time. Public sector budget functions according to Mardiasmo (2009: 63-66) are: a) budget as a planning tool; b) the budget as a control tool; c) budget as a fiscal policy tool; d) budget as a political tool; e) budget as a means of coordination and communication; f) budget as a performance assessment tool; g) budget as a motivational tool; h) budget as a tool for creating public space.

Performance approaches in budgeting are intended to address weaknesses in traditional budgets, especially weaknesses due to the absence of benchmarks that can be used to measure performance in achieving public service goals and objectives (Mardiasmo, 2009: 84). The purpose of performance-based budgets according to Robinson and Last (2009) is to increase the efficiency and effectiveness of spending carried out by connecting between public sector funding and the results they provide, through the use of systematic performance information. Strategic planning is structured as the first stage in performance-based budgeting. This activity includes the development of the organization's vision and mission, identifying opportunities and threats faced by the organization, determining the strengths and weaknesses of the organization, establishing long-term goals, making several alternative strategies, and selecting specific strategies to use. According to Gaspersz (2004: 9) a strategic planning process is said to be successful if it can answer the following questions: a) where are we now ?; b) where do we want to be in the future ?; c) how do we measure progress that has been achieved ?; d) how do we achieve our goals and objectives ?; e) how do we trace the progress that has been achieved?

Performance measurement is an activity of collecting, analyzing, and reporting data systematically and routinely that tracks the use of resources, the work produced, and the specific results achieved by an organization. The performance measurement is based on the organization's goals and objectives related to the organization's mission statement. Performance measurement systems must produce measurable outcomes that are directly related to a particular program that will be used as indicators for comparison of resource allocation over a certain period of time, eg decision making tool (Probst, 2009). Performance measures according to Bappenas (2009: 31) are divided into several levels, namely: a) input indicators; b) output indicators; c) outcome indicators; d) impact indicators.

The Balanced Scorecard was first introduced by Kaplan and Norton in 1992 departing from the hypothesis that the approach to measuring financial performance has not been able to help create long-term economic value for the company. According to Simons (2000) the balanced 
scorecard is seen as able to communicate the various interrelated goals that must be achieved by the company based on the innovation and "intangible" capabilities possessed. The balanced scorecard translates mission and strategy into goals and measures in four different perspectives, namely: a) financial perspective; b) customer perspective; c) internal business process perspective; d) learning and growth perspective. The purpose of the translation of vision, mission, and strategy into four balanced scorecard perspectives is to answer the following questions (Kaplan and Norton, 1996): a) what are the views or expectations of customers towards the company (customer perspective)? b) what should be the company's superiority (internal business process perspective)? c) what improvements can the company make to create sustainable value (learning and growth perspective)? d) how the company performance in the view of the shareholders (financial perspective)? The concept of the balanced scorecard that is widely used in the private sector is made some adjustments by Niven (2003: 32) to be used in the public sector and non-profit organizations.

Adjustments made by Niven (2003: 33) on the concept of balanced scorecard for the public sector are: a) the mission is placed at the peak of the balanced scorecard, public sector organizations prioritize the achievement of the mission compared to efficient budget allocation; b) the strategy remains the core of the balanced scorecard, determining strategic issues can help the organization to overcome the difficulties of establishing a directed, clear, and concise strategy; c) the customer perspective is placed higher, the main goal of public sector organizations is to meet satisfaction with the services provided to customers; $d$ ) financial perspective as a supporting factor for success or constraints in performing services; e) identify internal processes that add value to customers; f) learning and growth for employees as a basis for a good balanced scorecard.

Before implementing the strategy, the organization must determine the mission, values, and vision of the organization. The balanced scorecard will translate the mission, values, vision and strategy into performance metrics that can be used to measure success in meeting the overall objectives of the organization (Niven, 2003: 101).

\subsection{Mision}

Lichiello and Turnock (1999, p.50-51) define mission as a comprehensive and concise statement that explains what the organization does, for whom, how, and why. Whereas according to Niven (2003: 102) the mission defines the core objectives and the main reasons for the existence of the organization (why we exist) which describes how the responsibility of an organization in serving the public interest. From the definition it can be concluded that mission is a comprehensive and concise statement that represents the main reason for the existence of the organization and its responsibilities in serving the public.

The characteristics of an effective mission statement according to Niven (2003: 103) are: a) simple and clear, the mission must reflect the goals to be achieved and stated clearly; b) but not too simple, besides not being over-stated, mission statements must not limit the scope of the organization; c) inspire change, the mission must inspire change in the organization, encourage organizational movement in the future, stimulate change and positive growth; d) long term in nature, the mission statement is long-term and becomes the basis for any decision making in the present or future organization; e) easy to understand and communicate, the mission must be written and expressed in a language that is easily understood by everyone involved in the organization. 


\subsection{Values}

Niven (2003: 111) states that value is an eternal principle that guides organizations. Values show the beliefs held firm in the organization and shown through the daily behavior of all employees. Organizational value is an open statement about how each individual in the organization is expected to behave.

Patrick Leoncini in Niven (2003: 112) suggests that organizational values must be "aggressively authentic", in this case the organization must develop values that are consistent with the goals of the organization. There is no measure of right or wrong in an organizational value, every organization must be able to find core values that shape the essence of the organization and maintain the application of the core values of the organization.

\subsection{Vision}

Vision is a representation of what you believe to be the shape of your organization in the future in the eyes of customers, employees, owners and stakeholders (Morrisey, 1997: 6). While according to Paterson and Harahap (2010: 11) states that the vision is a view that is oriented towards the future based on public values, and can reveal the benefits provided and challenging for the members of the organization. Niven (2003) states that vision is a statement of organizational goals that will be achieved in a measure of a certain time $(5,10$, or 15 years) that must concretely describe what is to be achieved and become the basis for formulating strategies and objectives of the organization. Peter Sange, an expert in organizational learning, argues that the vision of translating mission into meaningful results and guiding the assumption of time, energy, and resources (Niven, 2003: 116). From the definition it can be concluded that vision is the revelation of the goals of the organization that have a certain period of time that describes the shape of the organization in the future based on the value of the organization that is believed and can show the benefits of the organization.

Benefits of the vision statement (Niven, 2003: 122): a) provides guidance, vision provides clear and interesting guidance about the future and what is needed for success; b) creates positive tension, the vision must be able to encourage each individual to achieve higher organizational performance; c) leadership complements, clear vision and inspiration can empower individuals to make decisions that are in accordance with organizational goals; d) forces the discussion of trade-offs, the vision must be focused on guiding high-level decision making but is flexible to encourage active dialogue and individual initiative; e) appeals to a variety of senses, the best vision resonates within each individual and appeals to all parties involved in the organization.

\subsection{Strategy}

Bill Ryan defined strategy as not about being everything to everyone. Deciding when to say no, and determining what should not be done is an important component of the strategy. Meanwhile Henry Mintzberg argues that making a strategy is a very complex process, and sometimes involves a highly sophisticated and subtle human subconscious element (Niven, 2003: 129 - 130). Furthermore, Porter emphasized that strategy is a different activity to produce a unique mix of values. The essence of the strategy for organizations is to choose a strategic position that can be claimed as their own (Henry, 2011: 5). From the definition it can be concluded that the strategy is a series of complex and different activities to produce a unique value for the organization in achieving its objectives. 
From the many opinions of experts regarding strategy, there are five main principles of strategy (Niven, 2003: 129), namely: a) Different Activities, strategies are how to choose different activities with the aim of achieving unique and valuable positions within the organization; b) trade-offs, strategies are about choosing what the organization must do or not do and creating value from that strategic position; c) fit, selected activities must be compatible with each other for ongoing success; d) continuity, the strategy is the result of crystallizing thoughts on basic issues about how an organization offers value to customers; e) various thought processes, strategies not only involve detailed and complex analysis, but also broad conceptual understanding of the organization, environment, and others.

\subsection{Building Performance Measures}

Niven (2003: 186) states that performance measures are standards used to evaluate and communicate performance against desired results. The function of performance measures is as a driving force to act as expected, as a guide for each individual in the organization in contributing to the achievement of organizational goals, and as an ingredient for management to determine progress towards achieving strategic goals (Niven, 2006: 144).

The measure of performance created must be able to translate strategic targets contained in the strategic map. Performance measurement criteria that can be taken into consideration in choosing performance measures to translate organizational strategies according to Niven (2008: 228 - 230), namely: a) performance measures must be aligned with the strategy; b) easy to understand; c) has a causal relationship; d) Can be renewed; e) Data can be accessed; f) Measures of performance used can describe actual processes or activities; g) avoid sizes that use dates; h) use quantitative data; i) can analyze the dysfunctional performance measures.

\subsection{Targets and Initiatives}

The target is the result to be achieved from the performance measure. By comparing the target and the results of actual performance, valuable information will be obtained as a reference in action, decision making, and allocation of resources. The target is also a communication tool within the organization to convey the level of performance needed to achieve organizational goals. In addition, the target also functions as a tool for organizations and customers to measure the effectiveness and accountability of organizations (Niven, 2003: 215 - 216).

Target types according to Niven (2006: 181 - 183): a) long-term targets, between 10-30 years and require extraordinary effort to achieve them; b) midrange targets, the target range between 3 - 5 years which is a description of the changes that the organization needs to make in that period of time; c) incremental targets, is the annual target of the organization that functions as an early warning system and provides timely feedback related to achieving medium-term targets and long-term targets.

Initiatives are programs, activities, projects that are carried out to help achieve the performance targets of each strategic goal that are needed by public sector organizations (Niven, 2008: 245 - 246). There are four stages that the organization must do in making targets according to Niven (2006, 189), namely: a) inventory of all current strategic initiatives of the organization; b) map all the strategic initiatives into the objectives contained in the 
strategic map; c) eliminate initiatives that are not strategic and develop lost initiatives; d) prioritizing the remaining strategic initiatives.

\subsection{Integrating the Budget with the Balanced Scorecard}

Efforts to link the budget with the performance measurement system began in the 1990s which was marked by the promulgation of the 1993 Government Performance and Results Act (GPRA) in the United States. This rule regulates the use of strategic plans, strategic objectives, and performance measurement systems in all government agencies (federal agencies). Then, in 1999 GPRA required all government agencies to integrate the budget with measuring performance in their reports (Niven, 2008: 277).

The balanced scorecard is proven to have advantages over the performance measurement systems of other models, so that public sector or government organizations connect the budget with the measurement of balanced scorecard performance.

The steps in integrating the budget with balanced scorecard are as follows (Niven, 2008: 279282): a) make a plan; b) make or improve the strategy map and the balanced scorecard at the top level of the organization that outlines strategic objectives, sizes and targets for the organization; c) cascading the balanced scorecard which outlines measures and targets, as well as effective strategic initiatives; d) compile data on resources needed to support initiatives and strategic objectives in the balanced scorecard; e) evaluation and research on proposed initiatives, targets and budgets.

The advantage of integrating the budget and balanced scorecard according to Niven (2008: 283-284) are: a) budget allocations are arranged based on facts; b) building collaboration between the budget and the balanced scorecard; c) strengthen the strategy, by preparing a budget to make each part involved in the organization must understand the organization's strategies that have been set.

\section{Research Methods}

The study used a descriptive qualitative research method with a case study approach. Patton (2002) defines qualitative research as research that tries to understand phenomena in natural settings and contexts (not in the laboratory) where researchers do not try to manipulate observed phenomena. While Cresswell (2010) defines a case study as a research strategy where researchers examine it into a program, event, activity, process or group of individuals. According to Stake (1995) in the case study approach is limited by time and activity and the researcher collects complete information using a variety of data collection procedures based on predetermined time (Wardhanie, Akram, and Firmansyah, 2017).

The data used in this study are primary data and secondary data. Primary data is the result of interviews with resource persons, including officials and employees at the Planning and Finance Bureau, Bureau of Human Resources and Organization and Governance, Bureau of Performance Accountability and Bureaucratic Reform, and officials / employees who took part in preparing the Cabinet Secretariat's strategic plan 2015 - 2019. While secondary data consists of the Cabinet Secretariat DIPA, reports on expenditure realization generated from the Agency Accounting System, and regulations related to the implementation of the central government budget.

Primary data collection is done by using interviews to several respondents who are considered to represent the entire organization and make direct observations of the process of preparing work plans, budgeting, and budget execution with the aim that the data obtained 
can be more accurate and clear. Secondary data was collected by obtaining the Cabinet Secretariat's strategic plans, DIPA documents, work plans, expenditure realization reports.

\section{Conclusion}

Based on the results of the analysis and discussion on the issues that are the subject of the study, it was found that the Cabinet Secretariat's vision statement did not describe the reason for the existence of the Cabinet Secretariat in the government and was too broad that it was difficult to determine the duties and functions of the Cabinet Secretariat itself. On the other hand, the vision statement is considered to have inspired enough to make changes in a direction that is better and quite easy to understand and communicate.

The Cabinet Secretariat does not yet have a strategy map, and this study devised a proposal for a strategy map for the Cabinet Secretariat which refers to each perspective in the balanced scorecard based on the SWOT analysis and vision, mission and objectives of the Cabinet Secretariat. In addition, this study also adds a number of strategic targets apart from the strategic targets listed in the 2015-2019 Cabinet Secretariat strategic plan with reference to each perspective in the balanced scorecard.

The Cabinet Secretariat does not yet have a balanced scorecard that can translate vision, mission and strategy as a communication tool and management tool in assessing performance and achieving organizational goals. For this reason, this study designs a balanced scorecard based on the strategy map and the strategic objectives that have been designed.

In preparing its budget, the Cabinet Secretariat has not used the balanced scorecard approach so the proposed budget is a repetition of the previous year's budget. By using the balanced scorecard approach in preparing budgets, it is expected that the budget prepared can be more focused in achieving the objectives of the Cabinet Secretariat. To link the budget with the balanced scorecard, the step that must be taken is cascading the balanced scorecard organization to the organizational unit below and the next step is to formulate strategic activities and calculate the budget that supports these activities.

From the results of the study it can be concluded that using a balanced scorecard can help organizations to develop budgets that focus on activities that have an influence on achieving targets and also support achieving the vision, mission and strategy of the Cabinet Secretariat. Budget allocation can be done rationally by considering the relationship between the proposed activity and the contribution of the proposal in achieving the target so that the budget discussion process becomes more directed and can produce quick and appropriate decisions.

\section{REFERENCE}

Wardhanie, R., Akram, A., \& Firmansyah, F. (2017). Agency Theory To Analyze Slow Back Loaded Expenditure Of Deconcentration Implementation (Case Study On Province Ntb). E-Proceeding Stie Mandala.

Mardiasmo (2009). Akuntansi Sektor Publik. Yoyakarta: Andi Offiset.

Baswir, Revrisond. (2000). Akuntansi Pemerintahan Indonesia. Yogyakarta: BPFE.

Bastian, Indra. (2006). Akuntansi Sektor Publik: Suatu Pengantar. Jakarta: Penerbit Erlangga.

Robinson, M., dan Duncan Last. (2009) Techincal Notes and Manual: A Basic Model of Performance-Based Budgeting. Washington, D.C.: International Monetary Fund 
Hager, G., A. Hobson, dan Ginny Wilson (2001) Performance-Based Budgeting: Concepts and Examples, Research Report No. 302. Frankfort, Kentucky: Legislative Research Commission.

Direktorat Jenderal Anggaran Kementerian Keuangan Republik Indonesia. (2018), Anggaran berbasis kinerja. http://www.anggaran.depkeu.go.id/dja/edef-konten-view.asp?id=628 (diakses pada tanggal 13 Oktober 2018).

Kaplan, Robert S. \& Norton, David P. (2007) The Balanced Scorecard Translating Strategy into Action. Harvard Business Business School Press

Kaplan, Robert S. \& Norton, David P. (1992) The Balanced Scorecard Measures that Drive Performance. Harvard Business Review

Kaplan, Robert S. \& Norton, David P. (2007) Using The Balanced Scorecard as a Strategic Management System. Harvard Business Review

Niven, P. R. (2003) Balanced Scorecard: Step-by-step for Government and Nonprofit Agencies. John Wiley \& Sons.

Niven, P. R. (2006) Balanced Scorecard: Step-by-step Maximizing Performance and Maintaining Results. John Wiley \& Sons.

Niven, P. R. (2008) Balanced Scorecard: Step-by-step for Government and Nonprofit Agencies $2^{\text {nd }}$ edition. John Wiley \& Sons.

Lichiello, Patricia and Turnock, Bernard. Guidebook for Performance Measurement.

Mahsun, Mohamad. (2013). Pengukuran Kinerja Sektor Publik. Yogyakarta: Fakultas Ekonomi dan Bisnis UGM.

Marr, Bernard. (2006). Strategic Performance Management: Leveraging and Measuring Your Intangible Value Drivers.

Probst, A. (2009). Performance measurement, benchmarking \& outcome-based budgeting for Wisconsin local government. Local Government Center, University of WisconsinExtension

Kedeputian Evaluasi Kinerja Pembangunan (2009). Pedoman Evaluasi dan Indikator Kinerja Pembangunan. Badan Perencanaan Pembangunan Nasional.

Renyowijoyo, Muindro. (2013). Akuntansi Sektor Publik: Organisasi Non Laba. Jakarta: Penerbit Mitra Wacana Media.

Baswir, Revrisond. (2000). Akuntansi Pemerintahan Indonesia. Yogyakarta: BPFE.

Simons, Robert (2000). Performance Measurement \& Control Systems for Implementing Strategy: Text \& Cases. Prentice Hall

Peraturan Presiden Nomor 25 Tahun 2015 tentang Sekretariat Kabinet

McCue, Cliff., and Prier, Eric. Using Agency Theory to Model Cooperative Public Purchasing.

Legrain, Amuary., and Auwers, Tom. (2006). The Principal-Agent Model and The Network Theory as Framework for Administrative Procedures Social Security in Belgium. EGPA conference "Public Manager Under Pressure: Between Politics, Professionalism and Civil Society", Milan, September 6-9, 2006 (Study group VI : Governance of Public Sector Organizations). 